\title{
Environmental drivers are more important for structuring fungal decomposer communities than the geographic distance between streams
}

\author{
Sofia Duarte ${ }^{1, *}$, Fernanda Cássio $^{1,2}$ and Cláudia Pascoal ${ }^{1,2}$ \\ ${ }^{1}$ Centre of Molecular and Environmental Biology (CBMA), Department of Biology, University of Minho, Cam- \\ pus de Gualtar, 4705-057, Braga, Portugal. \\ ${ }^{2}$ Institute of Science and Innovation for Bio-Sustainability (IB-S), University of Minho, Campus de Gualtar, \\ 4710-057 Braga, Portugal. \\ *Corresponding author: sduarte@bio.uminho.pt
}

Received: 09/11/16

Accepted: 13/01/17

\begin{abstract}
Environmental drivers are more important for structuring fungal decomposer communities than the geographic distance between streams

One of the major challenges in microbial ecology is to unravel the mechanisms that operate at the spatial-temporal scales structuring microbial communities and how these communities respond to environmental change. It has been argued that the biogeography of microorganisms solely reflects the influence of contemporary environmental variation and "everything is everywhere". Since the discovery of the key role that decomposer fungi, in particular aquatic hyphomycetes, play in leaf-litter decomposition in streams, mycologists were interested in deciphering several ecological aspects, including the factors that shape the distribution of these communities in streams. At local and regional scales, community structure is affected by several abiotic factors such as $\mathrm{pH}$, temperature, conductivity and nutrients in the stream water, but at a global scale, community similarity also decreases as a function of the geographic distance. However, very few attempts have been conducted to assess the relative influence of environmental versus geographic factors in structuring decomposer fungi in streams. In the current study, we attempted to fulfil this lacuna by quantifying the relative contributions of environmental factors versus spatial factors to community composition, by using data of species composition and environmental (temperature, $\mathrm{pH}$, conductivity and nutrient concentrations) and spatial variables (latitude, longitude and altitude), collected during a recent extensive literature search. Alfa diversity was negatively affected by $\mathrm{pH}$, conductivity, nitrates and phosphorus concentrations in the stream water. On the other hand, a unimodal type relationship was found between species richness and temperature, latitude or altitude. Beta-diversity was also strongly influenced by environmental factors, in particular conductivity, nitrates and phosphorus concentrations, and $\mathrm{pH}$ in stream water, but also by the geographic location (latitude and longitude) of the study sites. However, when the effects were disentangled a significant effect was found only for environmental variables. This suggests that streamdwelling decomposer fungi may exhibit biogeographic patterns, but as proposed by Baas-Becking "the environment selects" and is in part responsible for the spatial variation of stream-dwelling decomposer fungi. However, our conclusions should be taken cautiously because our data were extracted from the literature and reflect a geographical bias in the collection effort. Thus, future investigations should involve broad-scale coordinated surveys, incorporating a larger number of streams in different latitudinal bands and along large environmental gradients, to better assess the relative importance of environmental and geographical factors in structuring fungal communities in streams.
\end{abstract}

Key words: Freshwater ecosystems, stream-decomposer fungi, spatial factors, environmental factors.

\section{RESUMO}

A variabilidade ambiental é mais importante para a estruturação das comunidades de fungos decompositores que a distância geográfica entre rios

Um dos grandes desafios da ecologia microbiana é elucidar quais os mecanismos que operam na estruturação espáciotemporal das comunidades microbianas e como estas comunidades respondem às alterações ambientais. Tem sido argumentado que a biogeografia dos microrganismos reflete apenas a influência da variabilidade ambiental. Desde a descoberta do 
papel chave que os fungos, em particular os hifomicetos aquáticos, desempenham na decomposição de material alóctone em rios, que os micologistas se mostraram interessados em decifrar vários aspetos ecológicos, incluindo os fatores que modelam a distribuição das suas comunidades nos rios. Às escalas local e regional, a estrutura das comunidades é afetada por vários fatores abióticos, mas à escala global a similaridade das comunidades parece diminuir com o aumento da distância geográfica. No entanto, muito poucas tentativas têm sido realizadas de forma a compreender a influência relativa de fatores ambientais versus fatores espaciais na estruturação dessas comunidades. No presente estudo tentámos colmatar esta lacuna quantificando as contribuições relativas de fatores ambientais versus fatores espaciais na estruturação das comunidades de fungos em rios, usando dados de composição em espécies e de variáveis ambientais (temperatura, pH, condutividade e concentrações de nutrientes) e espaciais (latitude, longitude e altitude) reunidos durante uma extensiva pesquisa bibliográfica. A diversidade alfa foi afetada negativamente pelo $\mathrm{pH}$, a condutividade e as concentrações de nitratos e fósforo na água do rio. Por outro lado, uma relação do tipo unimodal foi observada entre a riqueza em espécies e a temperatura, a latitude e a altitude. A diversidade beta foi influenciada por fatores ambientais, em particular, pela condutividade, as concentrações de nitratos e fósforo, e o pH na água do rio, mas também pela localização geográfica (latitude e longitude) dos locais de estudo. No entanto, quando os efeitos foram discriminados, um efeito significativo foi encontrado apenas para as variáveis ambientais. Estes resultados sugerem que os fungos decompositores dos rios parecem exibir padrões biogeográficos, mas tal como proposto por Baas-Becking "o ambiente seleciona” e é em parte responsável pela variação espacial destas comunidades nos rios. No entanto, as nossas conclusões devem ser cautelosas, uma vez que os dados usados no presente estudo foram extraídos da literatura e refletem um "bias” geográfico no esforço de colheita. As investigações futuras deverão envolver a prospeção da biodiversidade de forma coordenada no tempo, e em larga escala, de forma a compreendermos mais eficazmente a importância relativa dos fatores ambientais e geográficos na estruturação das comunidades de fungos em rios.

Palavras-chave: Ecossistemas de água doce, fungos decompositores, fatores espaciais, fatores ambientais.

\section{INTRODUCTION}

One of the major challenges in microbial ecology is to unravel the mechanisms that drive the spatial-temporal structuring of microbial communities and how these communities respond to environmental change (Logares et al., 2012). It has been often argued that the spatial distribution or biogeography of microorganisms solely reflects the influence of contemporary environmental variation, the so-called Baas-Becking hypothesis applied to microbial taxa stating that "everything is everywhere, but the environment selects" (Baas-Becking, 1934).

The most informative indicators of spatial turnover are the taxa-area and the distance-decay relationship (Fig. 1). The taxa-area relationship is among the few laws in ecology, establishing the relationship between the number of species ( $\alpha$-diversity) and the area (Arrhenius, 1921; Gleason, 1922) and it has been generalized as the power-law $S=c * A^{z}$, where $S$ is the number of species or taxa, $A$ is the sampled area and $c$ is the intercept in log-log scale. The species-area exponent $z$ can be assessed through the slope of the equation in the log-log scale, and represents the rate of species turnover across space (Arrhenius, 1921; Gleason, 1922) (Fig. 1a). An increase in the number of taxa with increasing sampled area is further evidence of spatial turnover among communities. The distance-decay relationship indicates how similarity in community composition ( $\beta$-diversity) changes with geographic distance (Green et al., 2004). Taxa-area relationships that reflect increasing spatial heterogeneity of community composition will exhibit a decrease in community similarity with increasing geographic distance (Fig. 1b).

Since the recognition of the key role that fungi, particularly aquatic hyphomycetes, play in leaf-litter decomposition in streams, mycologists have been interested in deciphering several related ecological aspects, including the factors that drive the distribution of fungal communities in streams (Ingold, 1942; Wood-Eggenschwiler \& Bärlocher, 1985). Aquatic hyphomycetes produce high amounts of large conidia with two predominant shapes: branched, and often tetraradiate or multiradiate, and sigmoid or worm-like and most of the species are readily identified ba- 
sed solely on its conidial morphology (morphospecies-based identification) (Gulis et al., 2005; Shearer et al., 2007). The capability of being active at extremely low temperatures and of producing a diverse array of extracellular enzymes able to break the "hard to digest" structural leaf compounds (Suberkropp, 1998; Bärlocher, 2005) are additional physiological features that make aquatic hyphomycetes the dominant microbial decomposers of leaf-litter in streams. By enzymatically macerating the leaf matrices, organic matter is converted by aquatic hyphomycetes into fungal biomass and mineralized, increasing litter palatability to stream detritivores (Suberkropp, 1998; Bärlocher, 2005).

At a first sight, based on the identification of morphospecies, aquatic hyphomycetes appear to have a worldwide distribution (WoodEggenschwiler \& Bärlocher, 1985; Shearer et al., 2007; Duarte et al., 2016), but at a regional scale abiotic factors can strongly influence community structure (e.g. temperature, Chauvet, 1991; Bärlocher et al., 2011; pH, Bärlocher \& Ros-

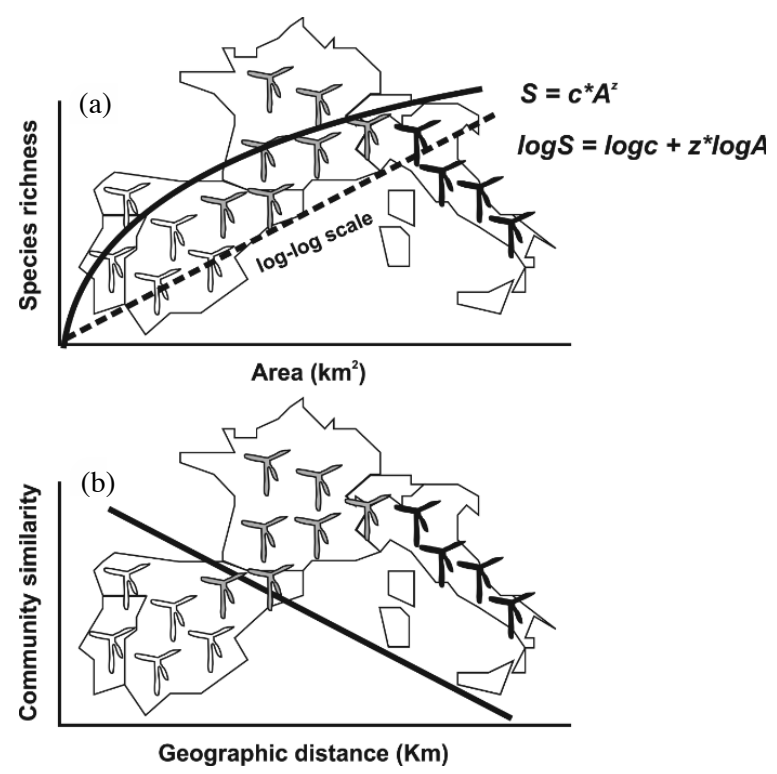

Figure 1. Schematic representation of the most informative indicators of spatial turnover used to assess biogeographic patterns among communities: the taxa-area relationship (a) and the distance-decay relationship (b). Representação esquemática dos indicadores mais informativos de variação espacial usados para aceder padrões biogeográficos entre as comunidades: a relação taxa-área (a) e a relação distância-decaimento (b). set, 1981; Casas \& Descals, 1997; conductivity, Wood-Eggenschwiler \& Bärlocher, 1983; nutrients, Pascoal et al., 2005a; Castela et al., 2008; Duarte et al., 2009). In an extensive literature review, community similarity of stream decomposer fungi was found to decrease as a function of latitude or geographic distance (Duarte et $a l ., 2016)$. In this follow-up study, we attempt to quantify the relative contributions of spatial factors (e.g. latitude, longitude, altitude) versus environmental factors (e.g. temperature, $\mathrm{pH}$, conductivity, nutrients) to community similarity patterns of stream decomposer fungi. Our specific aim is to understand if fungal decomposer communities differ among streams due to: i) spatial heterogeneity from environmental variation between locations, ii) the geographic distance between locations or iii) both.

\section{MATERIALS AND METHODS}

\section{Dataset}

In an attempt to quantify the relative importance of spatial versus environmental factors in structuring decomposer fungal communities in streams we assembled a sub-dataset from the one used in Duarte et al. (2016) by restricting to publications that reported data from: i) a minimum of 2 stream sites, differing in environmental characteristics and within the same region, per publication; ii) temperature, $\mathrm{pH}$, conductivity, nitrates $\left(\mathrm{N}-\mathrm{NO}_{3}^{-}\right)$and soluble reactive phosphorus (SRP); iii) geographic coordinates (latitude and longitude), from which altitude was found at http://www.mapcoordinates.net/en; iv) communities on decaying leaf litter; v) the percentage of contribution of each species for the total conidial production from leaf-litter to have a relative measure of the abundance of each species in the community. We followed a similar approach presented in Hughes-Martiny et al. (2006), where the authors focus on how the relative abundances of microbial taxa vary over space, rather than whether any taxa are truly restricted to particular geographic areas, since it is nearly impossible to show that a microbial taxon is absent from a 
given location (Hughes-Martiny et al., 2006). Data from publications based on diversity assessed in single stream sites was not used since it would increase the ratio reference/impacted sites, which would highly bias the analysis (data not shown). For publications where communities were sampled more than once, the average of all sampling times was used in the final analyses. Sites located in lakes, groundwater wells, pools, lentic habitats or in the hyporheic zone were also excluded from the analysis to reduce the variability due to habitat heterogeneity. Communities assessed from foam, water or other substrate types such as wood, pine needles or moss, were not included in the dataset to reduce the variability inherent to the use of different baits to assess conidial diversity. For each environmental parameter, data were all expressed in the same units to allow the direct comparison between studies (conductivity in $\mu \mathrm{S} / \mathrm{cm}, \mathrm{NO}_{3}^{-}$and SRP in $\mu \mathrm{g} / \mathrm{L}$ of $\mathrm{N}$ and $\mathrm{P}$, respectively). For the studies where more than one measure was available for the environmental parameters, average values were used.

\section{Data analyses}

The ordination of the stream sites according to the environmental variables conductivity, temperature, $\mathrm{pH}, \mathrm{N}-\mathrm{NO}_{3}^{-}$and SRP and the spatial factors altitude, latitude and longitude was performed using a principal component analysis (PCA). The relationships between environmental variables and between environmental variables, as well as PC scores, and $\alpha$-diversity were examined using Pearson correlation coefficients (Zar, 2010).

Canonical correspondence analysis (CCA) was used to assess the relationships between environmental variables and spatial factors and decomposer fungal communities (Legendre \& Legendre, 1998).

To determine the relative influence of spatial versus environmental factors in structuring decomposer fungal communities in streams, three matrices were constructed using our dataset (Hughes-Martiny et al., 2006): i) a biotic-similarity matrix based in the similarities of the decomposer fungal communities between each pair of

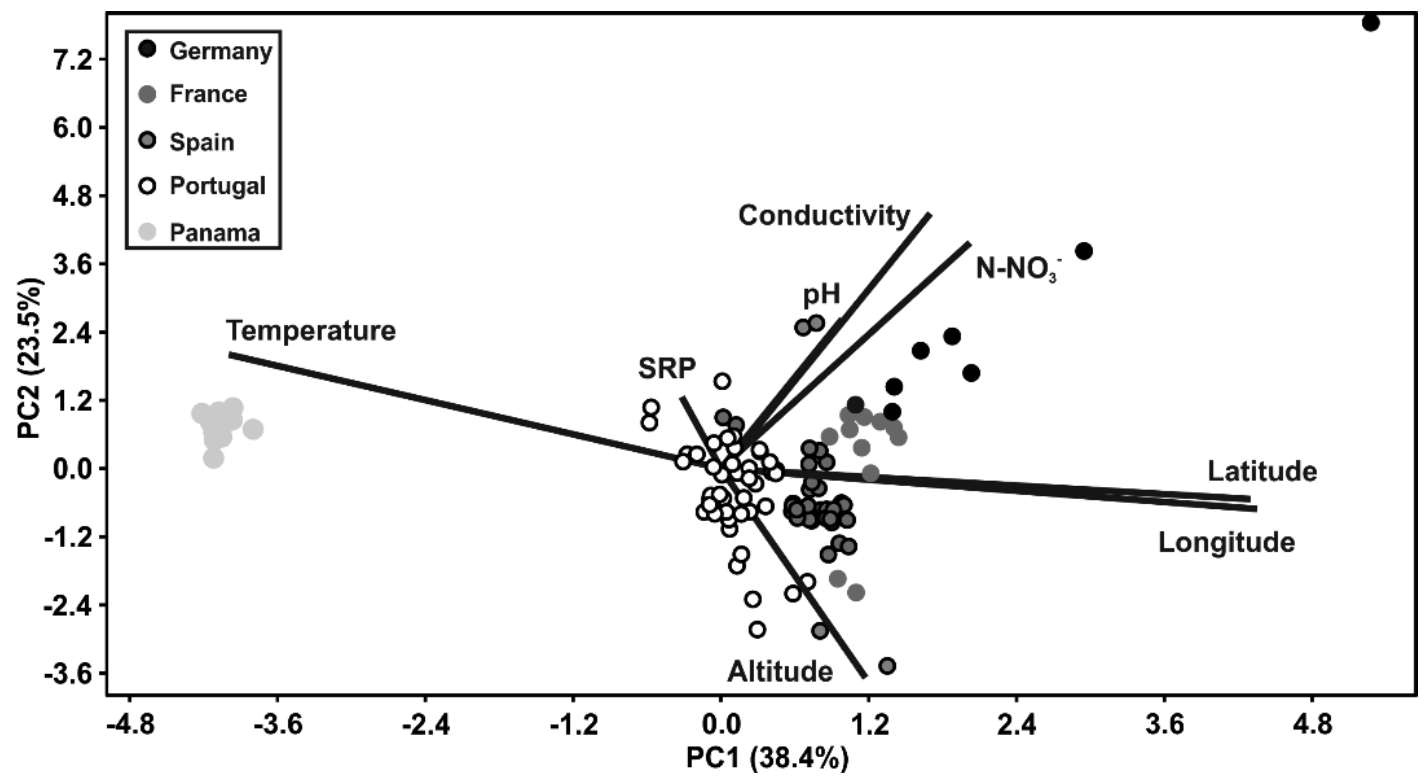

Figure 2. PCA ordination of the 111 stream sites according to the environmental variables $\mathrm{N}_{-} \mathrm{NO}_{3}^{-}$, $\mathrm{SRP}$, conductivity, $\mathrm{pH}$ and temperature and the spatial factors latitude, longitude and altitude. PC1 and PC2 explained $61.9 \%$ of the total variance. Ordenação de PCA dos 111 locais de acordo com as variáveis concentrações de $\mathrm{N}$-NO $\mathrm{O}_{3}^{-}$e SRP, condutividade, pH e temperatura e os fatores espaciais latitude, longitude e altitude. Os eixos PC1 e PC2 explicam $61.9 \%$ da variância total. 
stream sites, using the Bray-Curtis index (Legendre \& Legendre, 1998); ii) an environmental similarity matrix based on conductivity, temperature, $\mathrm{pH}, \mathrm{N}-\mathrm{NO}_{3}^{-}$and $\mathrm{SRP}$ values between each pair of sites, using Euclidean distance, and finally, iii) a geographic-distance matrix, using latitude and longitude values to get access to the actual geographic distances between each pair of stream sites (http://www.movabletype.co.uk/scripts/latlong.html). Biotic similarity was correlated with environmental similarity and geographic distance by using a Mantel test under 5000 permutations (Mantel, 1967). Partial Mantel tests, were further employed to disentangle the effects of environment versus geographic distance on community composition (Mantel, 1967). Data from fungal communities were square root transformed prior to construction of the biotic-similarity index. Raw values of the environmental variables were transformed to their standard normal deviate equivalent ([x-mean] divided by the standard deviation) to accommodate the different units of the different variables, before its use in PCA and CCA and before the construction of the environmental similarity matrix.

Linear regression models were used to assess the relationships between $\alpha$-diversity and $\mathrm{N}-\mathrm{NO}_{3}^{-}$, SRP, conductivity, $\mathrm{pH}$ and PC2 scores and between $\beta$-diversity (based on Bray-Curtis similarity) and environmental similarity (based on Euclidean distance) and pairwise geographic distance. Lorentzian models were used to assess the relationships between $\alpha$-diversity and temperature, latitude, altitude and PC1 scores.

Regression analyses were done in Statistica 8.0 for Windows (StatSoft, Inc., Tulsa, OK, USA). Correlation, PCA and CCA analyses and Mantel tests were conducted using PAleontological STatistics (PAST) version 2.17 for Windows (Hammer et al., 2001).

\section{RESULTS}

\section{Dataset}

By applying the criteria described in the Materials and Methods section, the final dataset included 111 decomposer fungal communities distributed by 43 sites in Portugal, 34 sites in Spain, 11 sites in France, 8 sites in Germany and 15 sites in Panama, from a total of 19 publications (Table S1, supplementary material available at www.limnetica.net/es/limnetica/36). The studies were conducted between 1999 and 2013 and the sites were located between a latitude of $9.1^{\circ} \mathrm{N}$ (Bärlocher et al., 2010, Panama) and $51.7^{\circ} \mathrm{N}$ (Solé et al., 2008, Germany), and between a minimum altitude of $45 \mathrm{~m}$ (Pascoal et al., 2003, Portugal) and a maximum altitude of $1.720 \mathrm{~m}$ (Casas et al., 2011, Spain). Alnus glutinosa was the leaf substrate more commonly used in these studies (65.8\% of the sites) while the exotic species Eucalyptus globulus was the less used (1.8\% of the sites). In $32.4 \%$ of the sites Quercus robur or mixed leaf species were used (Table S1). Most of the communities were assessed during autumn/winter (64.0\%), or in spring $(13.5 \%)$, while in Panama streams, communities were retrieved from decomposing mixed litter species during the wet season. More details of each site can be found in Table S1, or in the original publications.

\section{Environmental characterization of the sites}

The environmental characterization of the stream water of the 111 sites is detailed in Table S1. Most of the European sites exhibited stream water temperatures between 5 and $10^{\circ} \mathrm{C}(45.0 \%)$ or between 10 and $20^{\circ} \mathrm{C}(39.6 \%)$, while a lower $\%$, including all sites surveyed in Panama, exhibited temperatures higher than $20^{\circ} \mathrm{C}(15.3 \%)$. Most of the sites exhibited $\mathrm{pH}$ near neutrality (7.0-7.5) $(46.8 \%)$, while a lower percentage had slightly acidic $(<7.0)(25.2 \%)$ or slightly basic $(>7.5)$ $(27.9 \%) \mathrm{pH}$. Conductivity values varied between 100 and $500 \mu \mathrm{S} / \mathrm{cm}$ for $54.0 \%$ of the sites, while a lower \% exhibited values lower than $100 \mu \mathrm{S} / \mathrm{cm}$ (27.9\%) or higher than $500 \mu \mathrm{S} / \mathrm{cm}(18.0 \%)$. Sites with values higher than $1000 \mu \mathrm{S} / \mathrm{cm}$ included several of the German and also some Spanish stream sites with $\mathrm{pH}$ higher than 7.5. Most of the streams had $\mathrm{N}_{-} \mathrm{NO}_{3}^{-}$between 100 and $1000 \mu \mathrm{g} / \mathrm{L}$ $(36.0 \%)$ or 1000 and $5000 \mu \mathrm{g} / \mathrm{L}(39.6 \%)$, while a lower \% displayed values lower than $100 \mu \mathrm{g} / \mathrm{L}$ 
(18.0\%) or higher than $5000 \mu \mathrm{g} / \mathrm{L}$ (6.3\%). Most of the countries were represented in all ranges of $\mathrm{N}-\mathrm{NO}_{3}^{-}$, except in Germany, whose sites had all values higher than $1000 \mu \mathrm{g} / \mathrm{L}$. Two sites in Germany, displayed values higher than $10000 \mu \mathrm{g} / \mathrm{L}$ of $\mathrm{N}-\mathrm{NO}_{3}^{-}$. Soluble reactive phosphorus (SRP) concentrations were lower than $100 \mu \mathrm{g} / \mathrm{L}$ in more than $80 \%$ of the sites, while a lower $\%$ displayed concentrations between 100 and $1000 \mu \mathrm{g} / \mathrm{L}$ of SRP (17.1\%).

The PCA ordination of the 111 sites according to the stream water variables temperature,
$\mathrm{pH}$, conductivity, $\mathrm{N}-\mathrm{NO}_{3}^{-}$and $\mathrm{SRP}$ and the spatial factors altitude, latitude and longitude showed that PC1 and PC2 explained $61.9 \%$ of the total variance. The first PC axis separated Panama streams from the others, mainly due to differences in temperature, and German streams due to differences in latitude, longitude and conductivity and $\mathrm{N}-\mathrm{NO}_{3}^{-}$. The second $\mathrm{PC}$ axis described the altitudinal, but also the eutrophication gradient defined by $\mathrm{N}_{-} \mathrm{NO}_{3}^{-}$and $\mathrm{pH}$ and separated south European streams (Portuguese, Spanish and French) according to these variables (Fig. 2).
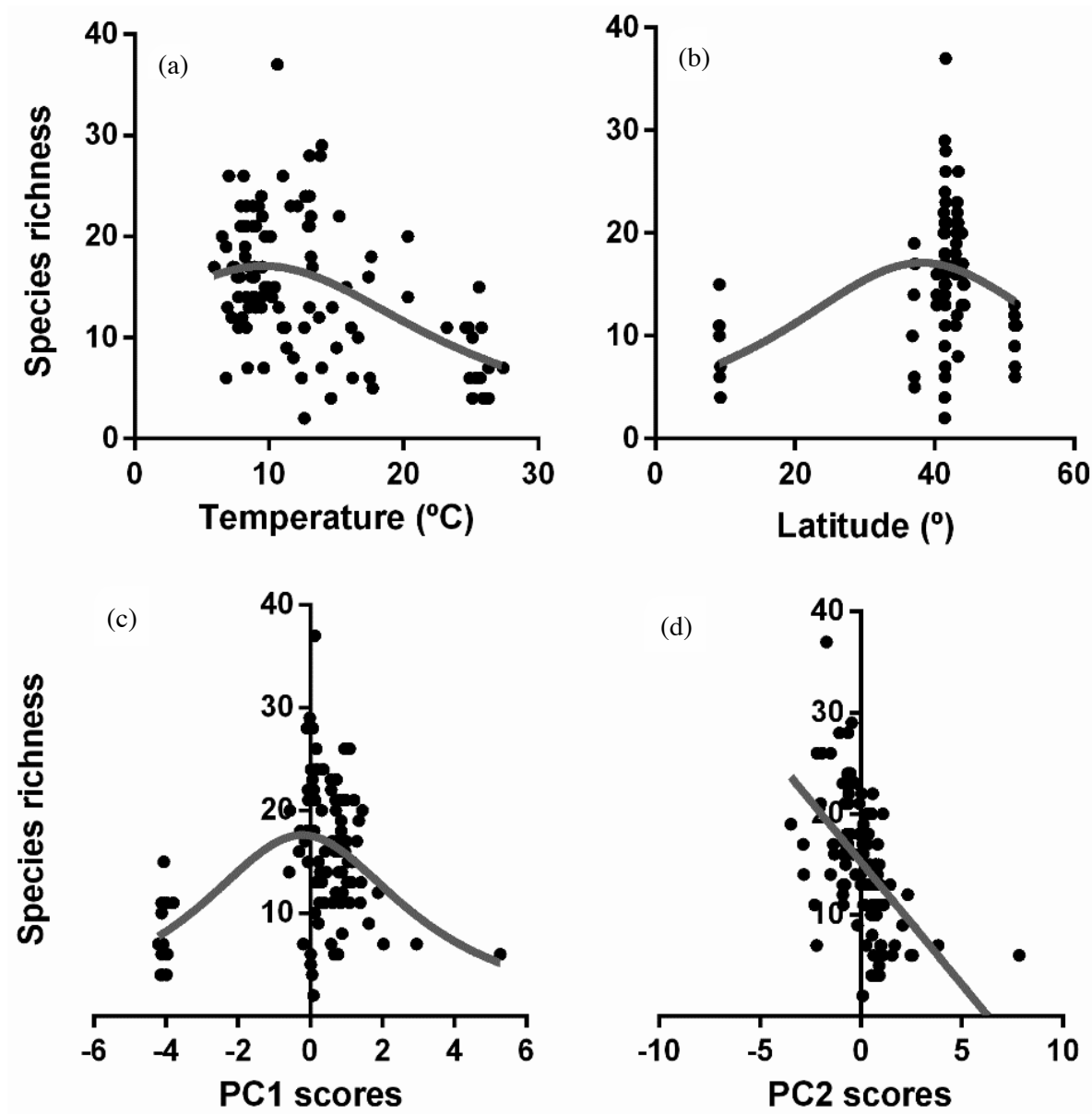

Figure 3. Relationship between $\alpha$-diversity and temperature (a), latitude (b) and PC1 (c) and PC2 (d) scores. Linear regression model gave the best fit for the relationship between $\alpha$-diversity and PC2 scores, while non-linear regression models (Lorentzian model) gave the best fits for the relationship between $\alpha$-diversity and temperature, latitude and PC1 scores. See Table S3 for more details about the regressions. Relação entre a diversidade alfa e a temperatura (a), a latitude (b), e as pontuações dos eixos PC1 (c) $e$ PC2 (d). O melhor ajuste de pontos para a relação entre a diversidade alfa e as pontuações do eixo PC2, foi obtido usando o modelo de regressão linear, enquanto para a relação entre a diversidade alfa e a temperatura, a latitude e as pontuações do eixo PC1 foi obtido usando modelos de regressão não linear (modelo de Lorentzian). Na Tabela S3 encontram-se mais detalhes das regressões. 
PC1 scores were mainly positively correlated with $\mathrm{N}_{-\mathrm{NO}_{3}^{-}}(r=0.45)$, latitude $(r=0.95)$ and longitude $(r=0.96)$ (Pearson's, $p<0.05)$ and negatively correlated with temperature (Pearson's, $r=-0.88, p<0.05)$, while a positive correlation was found between PC2 scores and $\mathrm{N}-\mathrm{NO}_{3}^{-}(r=0.69)$, conductivity $(r=0.78)$ and $\mathrm{pH}(r=0.46)$ (Pearson's, $p<0.05)$. On the other hand PC2 scores were negatively correlated with altitude (Pearson's, $r=-0.64, p<0.05$ ).

Nitrate concentrations $\left(\mathrm{N}-\mathrm{NO}_{3}^{-}\right)$were mainly positively correlated with conductivity $(r=0.68)$ (Pearson's, $p<0.05$ ). Latitude and longitude were negatively correlated with temperature (Pearson's, $r=-0.84$ and -0.86 , respectively, $p<0.05)$.

\section{Relative importance of spatial versus environmental factors in structuring decomposer fungal communities in streams}

A total number of 96 aquatic hyphomycete species ( $\alpha$-diversity) were found sporulating on leaf litter reported at the 111 sites, with a minimum of 2 and a maximum of 34 species found in Portuguese streams (Duarte et al., 2015 and Pascoal et al., 2005a, respectively). Six species occurred in at least 70 sites, with occurrence percentages between 0.1 and 98.3\%: Alatospora acuminata, Anguillospora filiformis, Heliscus lugdunensis, Flagellospora curvula, Lunulospora curvula and Tetrachaetum elegans (Table S2, supplementary material available at www.limneti ca.com).

Alfa diversity was positively correlated with altitude $(r=0.25)$, latitude $(r=0.37)$, longitude $(r=0.36)$ and PC1 scores $(r=0.29)$ (Pearson's, $p<0.05$ ) and negatively correlated with most of the stream water variables such as SRP $(r=-0.20)$, conductivity $(r=-0.38), \mathrm{pH}$ $(r=-0.24)$, temperature $(r=-0.43)$ (Pearson's, $p<0.05)$ and also with PC2 scores (Pearson's, $r=-0.50, p<0.05$ ) (see Fig. 3, Fig. S1 and Table S3, for more details about the regressions; supplementary material available at www. limnetica.com).

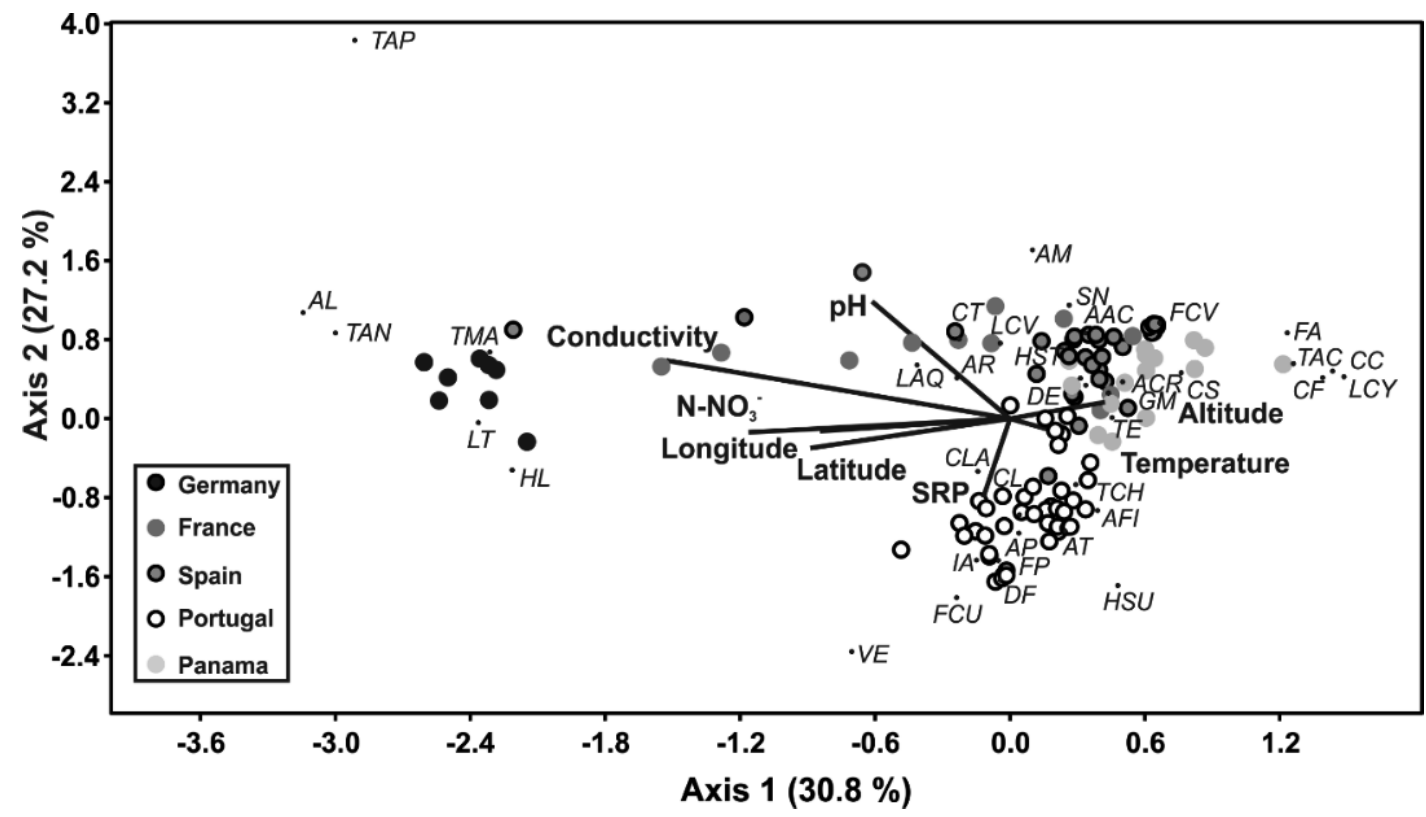

Figure 4. CCA diagram of the relationships between environmental variables and the spatial factors and the structure of fungal communities based on morphospecies at the 111 stream sites. The first two axes explained 58.0\% of the total variance. See Table $\mathrm{S} 2$ for the significance of species acronyms. Diagrama de CCA das relações entre as variáveis ambientais e os fatores espaciais e a estrutura das comunidades de fungos baseada em caracteres morfológicos nos 111 locais. Os primeiros dois eixos explicam $58.0 \%$ da variância total. Na Tabela 22 encontra-se o significado do acrónimo de cada espécie. 
From the 96 morphospecies, a total of 37 had a contribution $\geq 5 \%$ at least at one site and were used to assess the relationship between decomposer fungal community structure and environmental and spatial variables by canonical correspondence analysis (CCA). CCA showed that the first two axes explained $58.0 \%$ of the total variance. Conductivity $(r=-0.76), \mathrm{N}^{-\mathrm{NO}_{3}^{-}}$ $(r=-0.58)$, latitude $(r=-0.44)$ and longitude $(r=-0.42)$, and to a lesser extent altitude $(r=0.21)$ were significantly correlated with the first CCA axis, while SRP $(r=-0.40)$ and $\mathrm{pH}$ $(r=0.59)$ were significantly correlated with the second axis (Pearson's, $p<0.05$ ) (Fig. 4 and 5).

There were groups of species clearly associated with particular stream variables: 1) Anguillospora longissima, Tricladium angulatum, Tetracladium apiense, Lemonniera terrestris, T. mar- chanianum and Heliscus lugdunensis, occurred at high conductivity, $\mathrm{N}^{-\mathrm{NO}_{3}^{-}}$, latitude, longitude and $\mathrm{pH}$, and were dominant in Germany, France and also in some Spanish streams; 2) Flabellospora acuminata, Triscelophorus acuminatus, Campylospora filicladia, C. chaetocladia, and Lunulospora cymbiformis, were associated with high temperature and occurred mostly in Panama streams and 3) Varicosporium elodeae, Flagellospora curta, Heliscus submersus, Dimorphospora foliicola, F. penicillioides, Alatospora pulchella and Articulospora tetracladia were associated with high SRP, and occurred mostly in eutrophic Portuguese streams (Fig. 4 and 5).

Beta-diversity (community similarity) decreased significantly with both the environmental dissimilarity and the geographic distance (Linear regression, $y=-3.22 * x+37.56, r^{2}=0.14, p<$
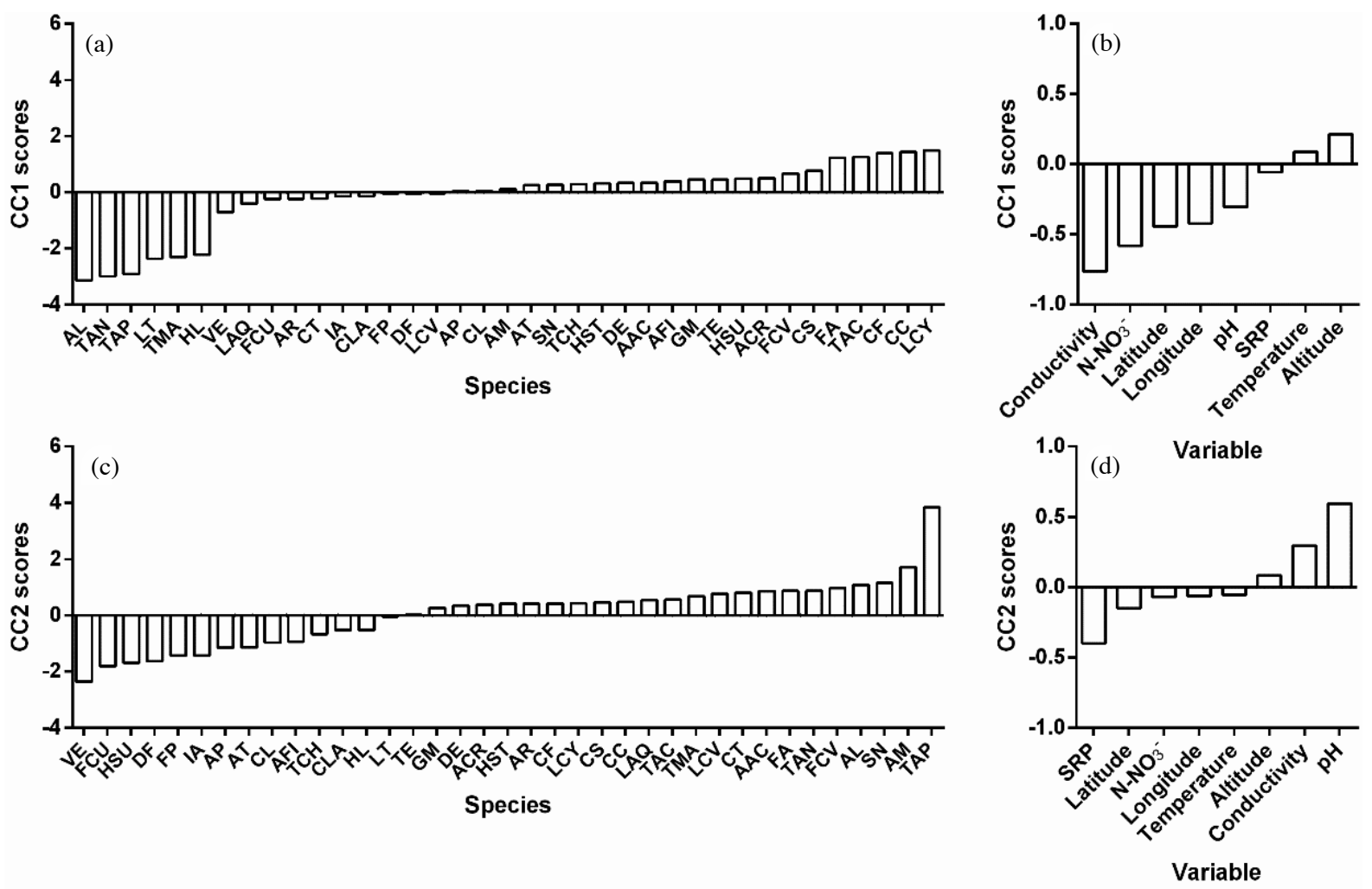

Figure 5. Species and variables scores on axis $1(\mathrm{a}, \mathrm{b})$ and axis $2(\mathrm{c}, \mathrm{d})$ of CCA of the relationships between environmental variables and the spatial factors and the structure of fungal communities based on morphospecies at the 111 stream sites. See Table S2 for the significance of species acronyms. Pontuação de cada espécie e de cada variável nos eixos 1 ( $a$, b) e 2 (c, d) da CCA das relações entre as variáveis ambientais e os fatores espaciais e a estrutura das comunidades de fungos baseada em caracteres morfológicos nos 111 locais. Na Tabela 22 encontra-se o significado do acrónimo de cada espécie. 
0.0001 and $y=-0.0010 * x+29.04, r^{2}=0.034$, $p<0.0001$; respectively) (Fig. 6). A Mantel test showed that all the three matrices: the bioticsimilarity matrix, the environmental-similarity matrix and the geographic-distance matrix were significantly correlated (Mantel test, $r=0.26$, $p=0.0002$ ). However, partial Mantel tests indicated that community similarity was significantly correlated with environmental similarity (Mantel test, $r=0.26, p=0.0002$ ), but not with geographic distance (Mantel test, $r=0.029$, $p=0.21$ ), suggesting that environmental variation between sites explained more the variation between communities rather than the difference in geographic distance.

\section{DISCUSSION}

In our study, the variation among fungal decomposer communities was better explained by the environmental variability than by the geographic distance. This lends support to the perspective of Baas-Becking that in the early thirties claimed that for microbes "everything is everywhere" and communities are solely controlled by environmental factors (Baas-Becking, 1934). However, as previously reported, the actual knowledge on the geographic distribution of aquatic hyphomycetes is highly biased due to the uneven level of sampling in various geographical areas (Shearer et al., 2007; Duarte et al., 2016). For instance, our dataset comprised data from five countries (Portugal, Spain, France, German and Panama), which obeyed to our established criteria and four are in temperate Europe. Even so, the spatial extent analysed was higher (ca. $9000 \mathrm{Km})$ than in any other study ever conducted until date (e.g. ca. $500 \mathrm{~km}$, Tolkkinen et al., 2013; ca. 200 km, Bergfur \& Sundberg, 2014; ca. 500 km, Heino et al., 2014). The same applies to the range of environmental variation across the sites, mainly in temperature, nutrient concentrations, and conductivity. The 111 sites were primarily separated along a latitudinal and temperature gradient in three main groups; i) Panama; ii) Portuguese and Spanish and iii) French and German stream sites (Fig. 2). Among the environmental variables, conductivity and nitrates also exerted a strong effect in differentiating the sites at a regional level (within Europe) (Fig. 2). Water chemistry greatly differed among drainage basins, ecoregions and biogeographical regions (Bärlocher et al., 2010, 2011; Pérez et al., 2012; Heino et al., 2014), and the differences among the sites of our dataset also reflected this variation.

Although the geographical occurrences of aquatic hyphomycetes are relatively well-studied compared to other freshwater fungi (e.g. freshwater ascomycetes) (Wood-Eggenchwiller \& Bärlocher, 1985; Shearer et al., 2007; Duarte et al., 2016), little is known about the influence of environmental factors on their geographical distribution. To our knowledge this is the first attempt to quantify the relative contributions of environment versus geographic factors to species richness and community structure (but see Heino et al., 2014). Alfa diversity was negatively correlated with most of the environmental variables such as nitrates, phosphorus, conductivity, $\mathrm{pH}$ and $\mathrm{PC} 2$ scores (that reflected the $\mathrm{pH}$, conductivity and nitrates gradient) (Fig. 3). Several studies conducted at local scales supported consistent negative effects found of eutrophication and conductivity on fungal diversity (Pascoal et al., 2003, 2005a; Lecerf \& Chauvet, 2008; Solé et al., 2008; Duarte et al., 2008, 2009, 2015), while for $\mathrm{pH}$, different trends had been found: an increase of diversity with the increase of $\mathrm{pH}$ (4.9-6.8: Chamier, 1987; 4.3-7.1: Baudoin et al., 2008); an unimodal relationship between diversity and $\mathrm{pH}$ (5.0-8.5: Bärlocher \& Rosset, 1981) or a decrease of diversity with $\mathrm{pH}$ (5.4-7.3: Bärlocher, 1987; 6.0-8.5, Wood-Eggenschwiller \& Bärlocher, 1983; 5.3-8.5: the current study). These opposite effects may be related to the wide $\mathrm{pH}$ ranges found for optimal fungal growth (Suberkropp \& Klug, 1980; Chamier, 1985), as well as the different type of exoenzymes that can be produced by individual aquatic hyphomycete species constituting the communities and that can differ, depending on local conditions. For instance, polygalacturonases, cellulases, and hemicellulases are often more active under acid conditions, whereas pectin lyases generally have 
an optimum pH between 8 and 9 (Suberkropp \& Klug, 1980; Chamier, 1985).

On the other hand, the relationship between $\alpha$-diversity and temperature, latitude, longitude, altitude and PC1 scores (that reflected the temperature and latitudinal gradient) followed unimodal type relationships with diversity peaking at mid-values (Fig. 3). Our analysis supports previous evidence suggesting that aquatic hyphomycete diversity peaks at mid-latitudes (Shearer et al., 2007; Jabiol et al., 2013; Duarte et al., 2016), but we must also take into account that more than $85 \%$ of the sites compiled in the current dataset were located in temperate regions $\left(37^{\circ}\right.$ to $\left.52^{\circ}\right)$. Thus, a temperature effect is more likely to be driving the observed pattern than the latitudinal differences per se. Although many aquatic hyphomycete species appear to be cosmopolitan, with distributions ranging from the arctic to the tropics (Wood-Eggenschwiler \& Barlocher, 1985; Shearer et al., 2007; Jabiol et al., 2013; Duarte et al., 2016), the growth and sporulation of most species from temperate streams are strongly affected by temperature, often exhibiting temperature optima's between 10 and $25^{\circ} \mathrm{C}$ (Suberkropp, 1984; Chauvet \& Suberkropp, 1998; Geraldes et al., 2012; Duarte et al., 2013). The temperatures displayed at the sites gathered in the current dataset varied between 5.9 and $27.4^{\circ} \mathrm{C}$, which comprises the temperatures optima's for most aquatic hyphomycetes, and thus an unimodal pattern was the most expected to be found. The relationship between $\alpha$-diversity and altitude followed a similar pattern to that found with temperature and seems to peak at altitudes between 400 and $700 \mathrm{~m}$, probably because high mountain streams are generally less prone to the influence of anthropogenic pressures that can strongly reduce fungal diversity (Chauvet 1991; Pascoal et al., 2005b; Bärlocher et al., 2011; Casas et $a l ., 2011)$. Beta diversity (change in community structure) was strongly influenced by environmental factors, in particular by $\mathrm{pH}$, conductivity, nitrates and phosphorus concentrations in the stream water, but also by the geographic location (latitude and longitude) (Fig. 4-6). A closer look into the current dataset reveals what we have aforementioned: that water chemistry can vary significantly among biogeographical regions, and thus the effects of geographic distance on communities can be confounded by the fact that closer sites may share similar environmental conditions (Rouquette et al., 2013). On the other hand, compared to conductivity, nutrients and $\mathrm{pH}$, temperature appears to exert a minor role in structuring fungal communities (Fig. 4, 5). Previous reports pointed to a strong influence of the trophic status in structuring microbial decomposer communities in streams (Pascoal et al., 2005a,b; Castela et al., 2008; Duarte et al., 2009, 2015; Bärlocher et al., 2010; Geraldes, 2011; Pérez et al., 2013; Fernandes et al., 2015; Pereira et al., 2016) or $\mathrm{pH}$ (Wood-Eggenschwiler \& Bärlocher, 1983; Bärlocher, 1987; Baudoin et al., 2008), within the same climatic zone. But, at a larger extent, climate has been pointed as a primary predictive factor in structuring fungal decomposer communities in streams, evidenced by the higher similarity shared between distant tropical locations (e.g. South America, West Africa) than between tropical and temperate streams located within the same continent (Wood-Eggenschwiler \& Bärlocher, 1985; Duarte et al., 2016). Unfortunately, our dataset comprised only 15 sites in one tropical country (Panama) (Bärlocher et al., 2010), whose environmental gradients were not as large as those found among the temperate streams included in the dataset. Nevertheless, in the original study, aquatic hyphomycete communities separated pristine from rural and urban streams, with the former streams detaining lower levels of several inorganic nutrients and higher fungal diversities, than the rural and urban streams (Bärlocher et al., 2010).

One interesting point found in our study, was the association of particular aquatic hyphomycete species with specific environmental drivers (Fig. 5). Six species were related to high conductivity and nitrates in the stream water: Tricladium angulatum, Anguillospora longissima, Tetracladium apiense, T. marchalianum, Lemonniera terrestris and Heliscus lugdunensis (Fig. 5). All these species had been consistently found in highly polluted streams in Germany (Krauss et al., 2005, for a review; Solé et al., 
2008) with extremely high nitrate concentrations and conductivity. For instance, the highest concentration of nitrates found in these streams (at H4, Solé et al., 2008) was 6 times higher than the highest concentration of nitrates found among the other European stream sites (at Seye, Duarte et al., 2009). However, these German streams are also characterized by high concentrations of chloride and metals in stream water (Solé et al., 2008), and thus we cannot rule out an interaction of eutrophication with the other catchment scale effects. A group of seven species was associated with high levels of phosphorus in the stream water: Flagellospora curta, Heliscus submersus, Dimorphospora foliicola, Varicosporium elodeae, F. penicillioides, Alatospora pulchella and Articulospora tetracladia. The first three species have been consistently found in eutrophic streams in the Northwest of Portugal, in river basins highly impacted by industrial and agricultural activities (Pascoal et al., 2005a, b, Duarte et al., 2008, 2009, 2015). Clavariopsis aquatica and Clavatospora longibrachiata, which were previously related to nutrient enrichment in the stream water (Pascoal \& Cássio, 2004; Pascoal et al., 2003, 2005a, b; Artigas et al., 2008; Pérez et al., 2013), were also associated with increasing phosphorus concentrations (Fig. 5). On the other hand, Flabellospora acuminata, Campylospora chaetocladia, Triscelophorus acuminatus, C. fili- cladia and Lunulospora cymbiformis, were associated with high temperatures and the last three occur primarily in tropical climates (Goh, 1997; Santos-Flores \& Betancourt-López, 1997).

Aquatic hyphomycete communities can be strongly affected by several anthropogenic factors (eutrophication, Pascoal et al., 2005a; Castela et al., 2008; Duarte et al., 2009; acidity and metals, Baudoin et al., 2008) and have been proposed as indicators of freshwater ecosystems condition (Castela et al., 2008; Lecerf \& Chauvet, 2008; Solé et al., 2008). A major drawback is the fact that these communities are affected by several natural factors and undergo seasonal fluctuations (e.g. Nikolcheva \& Bärlocher, 2005), which has to be taken into consideration. In addition, most stressors in streams do not occur alone; for instance, eutrophication in streams often occur in conjunction with other pollutants, such as increased levels of metals, pesticides and other organic pollutants, which can also alter the composition of aquatic hyphomycete communities in streams (Pascoal et al., 2005a, b; Solé et al., 2008; Duarte et al., 2008; Lecerf \& Chauvet, 2008; Bärlocher et al., 2010). Thus, it remains difficult to predict which specific factor is driving the alterations.

Although the geographic distance also appear to exert a strong influence in structuring fungal decomposer communities in the canoni-
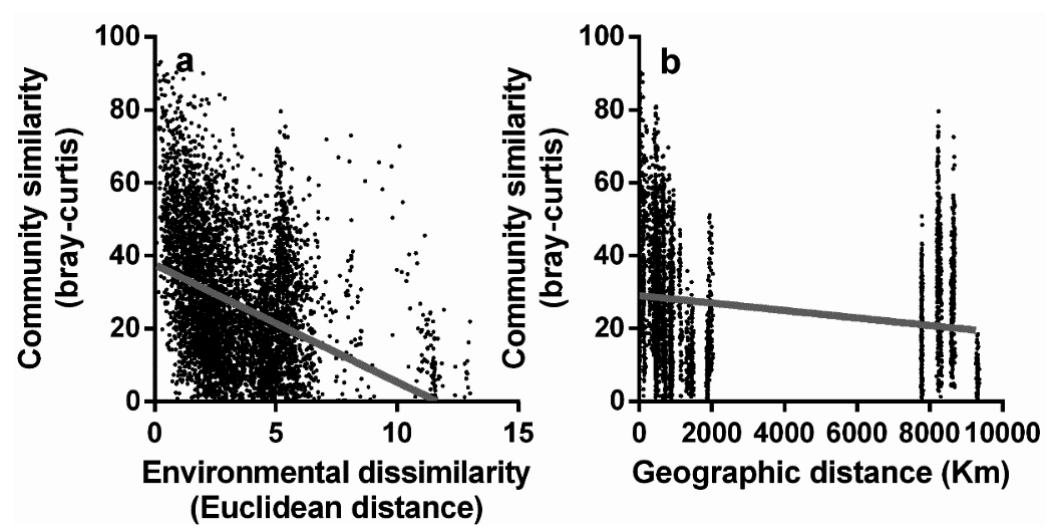

Figure 6. Relationship between community similarity, based on the Bray-Curtis index, and pairwise environmental dissimilarity, based on Euclidean distance (a), and geographic distance (b). Linear regression models gave the best fit for these relationships. Relações entre a similaridade das comunidades, baseada no índice de Bray-Curtis, e a dissimilaridade ambiental, baseada na distância de Euclidean (a), e a distância geográfica (b). O melhor ajuste de pontos para estas relações foi obtido através de modelos de regressão linear. 
cal correspondence analysis, when the effects of environmental and spatial factors were disentangled through partial Mantel tests, a significant effect was only found for environmental variables. This lends support to the traditional view in microbial ecology that the occurrence of a microbial species at a particular site is due to the suitable conditions provided by the surrounding environment rather than to its geographic location (Baas-Becking, 1934). But we cannot discard the hypothesis that stream-dwelling decomposer fungi may exhibit biogeographic patterns. As proposed by Baas-Becking "the environment selects" and is in part responsible for the spatial variation of decomposer fungi in streams. For instance, for other aquatic microbial eukaryotes, such as diatoms, species turnover is found to be strongly correlated with the geographic distance within a river network, even after the effect of environmental variation has been taken into account (Rouquette et al., 2013).

We must also take into consideration that the findings of the current study are based on the identification of morphospecies, which may overlook identical species that can be genetically different (cryptic species). Genetically different populations were found within the species Anguillospora filiformis, Flagellospora penicillioides, Geniculospora grandis, Lunulospora curvula, Tetrachaetum elegans (Duarte et al., 2012) and Articulospora tetracladia (Seena et al., 2012), at distant geographic locations. The application of molecular methods for analysing and identifying operational taxonomic units (OTUs) of microorganisms (Horner-Devine et al., 2004; Hughes-Martiny et al., 2006; Heino et al., 2014), in particular high throughput sequencing and bioinformatics, are expanding the catalogue of microbial taxa by orders of magnitude, suggesting that everything may not necessarily be everywhere. In a recent study, although the composition and richness of stream fungal communities, assessed by high throughput sequencing, were mostly related to water chemistry variables (e.g. pH, aluminium and total phosphorus), much of the variation was attributed to the shared effects of environmental and spatial predictors (Heino et al., 2014).
With marine fungi, both geographic distance and habitat appear to be important predictors of fungal community composition (Rämä et al., 2014; Tisthammer et al., 2016), but at a global-scale, environmental factors were stronger predictors of fungal community composition, than the geographic distance (Tisthammer et al., 2016).

Overall, our study gives support to the idea that environmental variation, in particular the trophic status of streams, play a greater role in structuring fungal decomposer communities than the geographic distance between streams. However, our dataset comprised data from only five countries, from which four are in temperate Europe, and, thus, our conclusions should be taken cautiously. Future investigations should involve broad-scale coordinated surveys (e.g. Jabiol et $a l ., 2013)$, incorporating a larger number of streams in different latitudinal bands and along larger environmental gradients, to better assess the relative importance of environmental and geographical factors in structuring fungal communities in streams. Identical methods to assess diversity should be used, and although much of the current knowledge on aquatic hyphomycete distribution patterns have been acquired based on the identification of morphospecies, we suggest that high throughput sequencing techniques should be employed due to its higher sensitivity and degree of differentiation between communities (Heino et al., 2014; Duarte et al., 2015; Fernandes et al., 2015).

\section{ACKNOWLEDGEMENTS}

This work was supported by the strategic programme UID/BIA/04050/2013 (POCI-01-0145FEDER-007569) funded by national funds through the FCT I.P. and by the ERDF through the COMPETE2020-Programa Operacional Competitividade e Internacionalização (POCI). Support from FCT to SD is also acknowledged (SFRH/BPD/109842/2015). The authors want also to thank to Eduardo Conde-Sousa for the help during the construction of the geographic-distance matrix used in the current study. 


\section{REFERENCES}

This list contains all the references cited in the manuscript and in the supplementary material (available at www.limnetica.com). ${ }^{*}$

\section{REFERENCES}

ARRHENIUS, O.W. 1921. Species and area. Journal of Ecology, 9: 95-99. DOI:10.2307/2255763

ARTIGAS, J., A.M. ROMANÍ, S.SABATER. 2008. Effect of nutrients on the sporulation and diversity of aquatic hyphomycetes on submerged substrata in a Mediterranean stream. Aquatic Botany, 88: 32-38. DOI:10.1016/j.aquabot.2007.08.005

BAAS-BECKING, L.G.M. 1934. Geobiologie of inleiding tot de milieukunde. W.P. Van Stockum and Zoon, The Hague, the Netherlands.

BÄRLOCHER, F. \& J. ROSSET. 1981. Aquatic hyphomycete spora of two black forest and two swiss jura streams. Transactions of the British Mycological Society, 76: 479-483. DOI:10.1016/S00071536(81)80076-9

BÄRLOCHER, F. 1987. Aquatic hyphomycete spora in 10 streams of New Brunswick and Nova Scotia. Canadian Journal of Botany, 65: 76-79.

BÄRLOCHER, F. 2005. Freshwater fungal communities. In: The fungal community: its organization and role in the ecosystem. J. Deighton, P. Oudemans \& J. White (eds.): 39-59. Taylor and Francis, CRC Press, Boca Raton, Florida, USA. DOI: 10.1201/9781420027891.ch3

*BÄRLOCHER, F., J.E. HELSON \& D.D. WILLIAMS. 2010. Aquatic hyphomycete communities across a land-use gradient of Panamanian streams. Fundamental and Applied Limnology/Archiv für Hydrobiologie, 177/3: 209-221. DOI:10.1127/18 63-9135/2010/0177-0209

BÄRLOCHER, F., M. STEWART \& D.S. RYDER. 2011. Analyzing aquatic fungal communities in Australia: impacts of sample incubation and geographic distance of streams. Czech Mycology, 63: 113-132.

BAUDOIN, J.M., F. GUÉROLD, V. FELTEN, E. CHAUVET, P. WAGNER \& P. ROUSSELLE. 2008. Elevated aluminium concentration in acidi-

\footnotetext{
* Papers from where the data used in the current study
} was extracted. fied headwater streams lowers aquatic hyphomycete diversity and impairs leaf-litter breakdown. $M i$ crobial Ecology, 56: 260-269. DOI:10.1007/s0024 8-007-9344-9

BERGFUR, J. \& C. SUNDBERG. 2014. Leaf-litterassociated fungi and bacteria along temporal and environmental gradients in boreal streams. Aquatic Microbial Ecology, 73: 225-234. DOI:10.3354/ ame 01721

CASAS, J.J. \& E. DESCALS. 1997. Aquatic hyphomycetes from Mediterranean streams contrasting in chemistry and riparian canopy. Limnetica, 13: 45-55.

*CASAS, J.J., M.O. GESSNER, D. LÓPEZ \& E. DESCALS. 2011. Leaf-litter colonisation and breakdown in relation to stream typology: insights from Mediterranean low-order streams. Freshwater Biology, 56: 2594-2608. DOI:10.1111/j.13652427.2011.02686.x

*CASTELA, J., V. FERREIRA \& M.A.S. GRAÇA. 2008. Evaluation of stream ecological integrity using litter decomposition and benthic invertebrates. Environmental Pollution, 153: 440-449. DOI:10. 1016/j.envpol.2007.08.005

CHAMIER, A.-C. 1985. Cell-wall degrading enzymes of aquatic hyphomycetes: a review. Botanical Journal of the Linnean Society, 91: 67-81. DOI: 10.1111/j.1095-8339.1985.tb01136.x

CHAMIER, A.-C. 1987. Effect of $\mathrm{pH}$ on microbial degradation of leaf litter in seven streams of the English Lake District. Oecologia, 71: 491-500. DOI:10.1007/BF00379287

CHAUVET, E. 1991. Aquatic hyphomycete distribution in South-Western France. Journal of Biogeography, 18: 699-706. DOI:10.2307/2845551

CHAUVET, E. \& K. SUBERKROPP. 1998. Temperature and sporulation of aquatic hyphomycetes. Applied and Environmental Microbiology, 64: 15221525 .

*DUARTE, S., C. PASCOAL \& F. CÁSSIO. 2008. High diversity of fungi may mitigate the impact of pollution on plant litter decomposition in streams. Microbial Ecology, 56: 688-695. DOI:10.1007/ s00248-008-9388-5

*DUARTE, S., C. PASCOAL, F. CÁSSIO, F. GARABÉTIEN \& J.-Y. CHARCOSSET. 2009. Microbial decomposer communities are mainly structured by trophic status in circumneutral and alkaline streams. Applied and Environmental Microbiology, 75: 6211-6221. DOI:10.1128/AEM.0097109 
DUARTE, S., S. SEENA, F. BÄRLOCHER, F. CÁSSIO \& C. PASCOAL. 2012. Preliminary insights into the phylogeography of six aquatic hyphomycete species. PLOS ONE, 7: e45289. DOI: 10.1371/journal.pone.0045289

DUARTE, S., I. FERNANDES, M.J. NOGUEIRA, F. CÁSSIO \& C. PASCOAL. 2013. Temperature alters interspecific relationships among aquatic fungi. Fungal Ecology, 6: 187-191. DOI:10.1016/ j.funeco.2013.02.001

*DUARTE, S., F. BÄRLOCHER, J. TRABULO, F. CÁSSIO \& C. PASCOAL. 2015. Stream-dwelling fungal decomposer communities along a gradient of eutrophication unraveled by 454 pyrosequencing. Fungal Diversity, 70: 127-148. DOI:10.1007/ s13225-014-0300-y

DUARTE, S., F. BÄRLOCHER, C. PASCOAL \& F. CÁSSIO. 2016. Biogeography of aquatic hyphomycetes: Current knowledge and future perspectives. Fungal Ecology, 19: 169-181. DOI:10.1016/ j.funeco.2015.06.002

*FERNANDES, I., A. PEREIRA, J. TRABULO, C. PASCOAL, F. CÁSSIO \& S. DUARTE. 2015. Microscopy- or DNA-based analyses: Which methodology gives a truer picture of stream-dwelling decomposer fungal diversity? Fungal Ecology, 18: 130-134. DOI:10.1016/j.funeco.2015.08.005

*GERALDES, P. 2011. Fungal communities and functional measures as indicators of stream ecosystem health. M.Sc. Thesis. University of Minho, Portugal.

GERALDES, P., C. PASCOAL \& F. CÁSSIO. 2012. Effects of increased temperature and aquatic fungal diversity on litter decomposition. Fungal Ecology, 5: 734-740. DOI:10.1016/j.funeco.2012.05.0 07

GLEASON, H.A. 1922. On the relation between species and area. Ecology, 3: 158-162. DOI:10.2307/ 1929150

GOH, T.K., 1997. Tropical freshwater hyphomycetes. In: Biodiversity of Tropical Microfungi. K. D. Hyde (ed.): 189-227. Hong Kong University Press, Hong Kong.

GREEN, J.L., A.J. HOLMES, M. WESTOBY, I. OLIVER, D. BRISCOE, M. DANGERFIELD, M. GILLINGS \& A.J. BEATTIE. 2004. Spatial scaling of microbial eukaryote diversity. Nature, 432: 747-750. DOI:10.1038/nature03034

GULIS, V., L. MARVANOVÁ \& E. DESCALS. 2005. An illustrated key to the common temperate species of aquatic hyphomycetes. In: Methods to study litter decomposition: a practical guide. M.A.S. Graça, F. Bärlocher \& M.O. Gessner (eds.): 153-168. Springer, Dordrecht, Netherlands.

HAMMER, Ø., D.A.T. HARPER \& P.D. RYAN. 2001. PAST: Paleontological Statistics Software Package for Education and Data Analysis. Palaeontologia Electronica, 4(1): 9 pp.

HEINO, J., M. TOLKKINEN, A.M. PIRTTILÄ, H. AISALA \& H. MYKRÄ. 2014. Microbial diversity and community-environment relationships in boreal streams. Journal of Biogeography, 41: 2234-2244. DOI:10.1111/jbi.12369

HORNER-DEVINE, M.C., M. LAGE, J.B. HUGHES \& B.J.M. BOHANNAN. 2004. A taxa-area relationship for bacteria. Nature, 432: 750-753. DOI: 10.1038/nature03073

HUGHES-MARTINY, J.B., B.J. BOHANNAN, J.H. BROWN, R.K. COLWELL, J.A. FUHRMAN, J.L. GREEN, M.C. HORNER-DEVINE, M. KANE, J.A. KRUMINS, C.R. KUSKE, P.J. MORIN, S. NAEEM, L. ØVREÅS, A.-L. REYSENBACH, V.H. SMITH \& J.T. STALEY. 2006. Microbial biogeography: putting microorganisms on the map. Nature Reviews Microbiology, 4: 102-112. DOI: 10.1038/nrmicro1341

INGOLD, C.T. 1942. Aquatic hyphomycetes of decaying alder leaves. Transactions of the British Mycological Society, 25: 339-417. DOI:10.1016/ S0007-1536(42)80001-7

JABIOL, J., A. BRUDER, M.O. GESSNER, M. MAKKONEN, B.G. MCKIE, E.T.H.M. PEETERS, V.C. A VOS \& E. CHAUVET. 2013. Diversity patterns of leaf-associated aquatic hyphomycetes along a broad latitudinal gradient. Fungal Ecology, 6: 439-448. DOI:10.1016/j.funeco.2013.04.002

KRAUSS, G., D. SCHLOSSER \& G.J. KRAUSS. 2005. Aquatic fungi in heavy metal and organically polluted habitats. In: Biodiversity of fungi: their role in human life. N.H. Enfield (ed.): 221246. Science Publishers, USA.

*LECERF, A. \& E. CHAUVET. 2008. Diversity and functions of leaf-decaying fungi in human-altered streams. Freshwater Biology, 53: 1658-1672. DOI:10.1111/j.1365-2427.2008.01986.x

LEGENDRE, P. \& L. LEGENDRE. 1998. Numerical Ecology. Elsevier Science, Amsterdam, Holland.

LOGARES, R., E.S. LINDSTRÖM, S. LANGENHEDER, J.B. LOGUE, H. PATERSON, J. LAYBOURN-PARRY, K. RENGEFORS, L. TRANVIK \& S. BERTILSSON. 2012. Biogeography of bacterial communities exposed to progressive 
long-term environmental change. The ISME Journal, 7: 937-948. DOI:10.1038/ismej.2012.168

MANTEL, N. 1967. The detection of disease clustering and a generalized regression approach. Cancer Research, 27: 209-220.

*MARTÍNEZ, A., A. LARRAÑAGA, J. PÉREZ, E. DESCALS, A. BASAGUREN \& J. POZO. 2013. Effects of pine plantations on structural and functional attributes of forested streams. Forest Ecology and Management, 310: 147-155. DOI:10.101 6/j.foreco.2013.08.024

*MENÉNDEZ, M., E. DESCALS, T. RIERA \& O. MOYA. 2013. Do non-native Platanus hybrida riparian plantations affect leaf litter decomposition in streams? Hydrobiologia, 716: 5-20. DOI:10. 1007/s10750-013-1539-0

*MESQUITA, A., C. PASCOAL \& F. CÁSSIO. 2007. Assessing effects of eutrophication in streams based on breakdown of eucalypt leaves. Fundamental and Applied Limnology, 168/3: 221-230. DOI:10.1127/1863-9135/2007/0168-0221

NIKOLCHEVA, L. G. \& F. BÄRLOCHER. 2005. Seasonal and substrate preferences of fungi colonizing leaves in streams: traditional versus molecular evidence. Environmental Microbiology, 7: 270-280. DOI:10.1111/j.1462-2920.2004.00709.x

*PASCOAL, C., M. PINHO, F. CÁSSIO \& P. GOMES. 2003. Assessing structural and functional ecosystem condition using leaf breakdown: studies on a polluted river. Freshwater Biology, 48: 20332044. DOI:10.1046/j.1365-2427.2003.01130.x

*PASCOAL, C. \& F. CÁSSIO. 2004. Contribution of fungi and bacteria to leaf litter decomposition in a polluted River. Applied and Environmental Microbiology, 70: 5266-5273. DOI:10.1128/AEM.70.9. 5266-5273.2004

*PASCOAL, C., F. CÁSSIO \& L. MARVANOVÁ. 2005a. Anthropogenic stress may affect aquatic hyphomycete diversity more than leaf decomposition in a low-order stream. Archiv für Hydrobiologie, 162: 481-496. DOI:10.1127/0003-9136/ 2005/0162-0481

PASCOAL, C., L. MARVANOVÁ \& F. CÁSSIO. 2005b. Aquatic hyphomycete diversity in streams of Northwest Portugal. Fungal Diversity, 19: 109-128.

PEREIRA, A., J. TRABULO, I. FERNANDES, C. PASCOAL, F. CÁSSIO \& S. DUARTE. 2016. Spring stimulates leaf decomposition in moderately eutrophic streams. Aquatic Sciences, 17: 197-2017. DOI:10.1007/s00027-016-0490-3
*PÉREZ, J., E. DESCALS \& J. POZO. 2012. Aquatic hyphomycete communities associated with decomposing alder leaf litter in reference headwater streams of the Basque Country (northern Spain). Microbial Ecology, 64: 279-290. DOI:10. 1007/s00248-012-0022-1

* PÉREZ, J., A. BASAGUREN, E. DESCALS, A. LARRAÑAGA \& J. POZO. 2013. Leaf-litter processing in headwater streams of northern Iberian Peninsula: moderate levels of eutrophication do not explain breakdown rates. Hydrobiologia, 718: 41-57. DOI:10.1007/s10750-013-1610-x

RÄMÄ,T., J. NORDÉN, M.L. DAVEY \& G.H. MATHIASSEN. 2014. Fungi ahoy! Diversity on marine wooden substrata in the high North. Fungal Ecology, 8: 46-58. DOI:10.1016/j.funeco.2013.12. 002

ROUQUETTE, J.R., M. DALLIMER, P.R. ARMSWORTH, K.J. GASTON, L. MALTBY \& P.H. WARREN. 2013. Species turnover and geographic distance in an urban river network. Diversity and Distributions, 19: 1429-1439. DOI:10.1111/ ddi. 12120

SANTOS-FLORES, C.J. \& C. BETANCOURT-LÓPEZ. 1997. Aquatic and water-borne hyphomycetes (Deuteromycotina) in streams of Puerto Rico (including records from other neotropical locations). Caribbean Journal of Science Special Publication 2.

SEENA, S., S. DUARTE, C. PASCOAL \& F. CÁSSIO. 2012. Intraspecific variation of the aquatic fungus Articulospora tetracladia: an ubiquitous perspective. PLOS ONE, 7: e35884. DOI:10.1371/ journal.pone.0035884

SHEARER, A.C., E. DESCALS, B. KOHLMEYER, J. KOHLMEYER, L. MARVANOVÁ, D. PADGETT, D. PORTER, H.A. RAJA, J.P. SCHMIT, H.A. THORTON \& H. VOGLYMAYR. 2007. Fungal biodiversity in aquatic habitats. Biodiversity and Conservation, 16: 49-67. DOI:10.1007/ s10531-006-9120-Z

*SOLÉ, M., I. FETZER, R. WENNRICH, K.R. SRIDHAR., H. HARMS \& G. KRAUSS. 2008. Aquatic hyphomycete communities as potential bioindicators for assessing anthropogenic stress. Science of the Total Environment, 389: 557-565. DOI:10.1016/j.scitotenv.2007.09.010

*SRIDHAR, K.R., S. DUARTE, F. CÁSSIO \& C. PASCOAL. 2009. The role of early fungal colonizers in leaf-litter decomposition in Portuguese 
streams impacted by agricultural runoff. International Review of Hydrobiology, 94: 399-409. DOI:10.1002/iroh.200811154

SUBERKROPP, K. \& M.J. KLUG. 1980. The maceration of deciduous leaf litter by aquatic hyphomycetes. Canadian Journal of Botany, 58: 10251031. DOI:10.1139/b80-126

SUBERKROPP, K. 1984. Effect of temperature on seasonal occurrence of aquatic hyphomycetes. Transactions of the British Mycological Society, 82: 53-62. DOI:10.1016/S0007-1536(84)80211-9

SUBERKROPP, K. 1998. Microorganisms and organic matter decomposition. In: River Ecology and Management: lessons from the Pacific coastal ecoregion. R.J. Naiman \& R.E. Bilby (eds.): 120-143. Springer, New York, USA.

TISTHAMMER, K.H., G.M. COBIAN \& A.S. AMEND. 2016. Global biogeography of marine fungi is shaped by the environment. Fungal Ecology, 19: 39-46. DOI:10.1016/j.funeco.2015.09.003
TOLKKINEN, M., H. MYKRÄ, A.-M. MARKKOLA, H. AISALA, K.-M. VUORI, J. LUMME, A.M. PIRTILLÄ \& T. MUOKTA. 2013. Decomposer communities in human impacted streams: species dominance rather than richness affects leaf decomposition. Journal of Applied Ecology, 50: 1142-1151. DOI:10.1111/1365-2664.12138

WOOD-EGGENSCHWILER, S. \& F. BÄRLOCHER. 1983. Aquatic hyphomycetes in sixteen streams in France, Germany and Switzerland. Transactions of the British Mycological Society, 81: 371-379. DOI:10.1016/S0007-1536(83)80089-8

WOOD-EGGENSCHWILER, S. \& F. BÄRLOCHER. 1985. Geographical distribution of Ingoldian fungi. Verhandlungen des Internationalen Verein Limnologie, 22: 2780-2785.

ZAR, J.H. 2010. Biostatistical Analysis. Prentice Hall. New Jersey, USA.

Con la colaboración de:

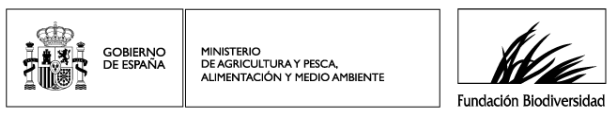

